\title{
LAW V. CANADA: FORMATTING EQUALITY
}

\section{Beverley Baines}

\section{ISSUE}

In Law v. Canada ${ }^{1}$ the Supreme Court of Canada held that Canada Pension Plan survivor benefits ${ }^{2}$ do not infringe Charter equality rights. ${ }^{3}$ Appearances to the contrary notwithstanding, Law's reasoning was not based on deference. Deference has acquired a technical meaning in Charter jurisprudence, one that Madame Justice Bertha Wilson was the first to identify. In Chaulk she used "deference" to refer to Chief Justice Lamer's "view that Parliament is not" required to seek and adopt "the absolutely least intrusive means of attaining its objective." ${ }^{n 4}$ Her usage signalled a significant change in one of the original tenets of the Oakes' test. ${ }^{5}$ More specifically, it signified that the Chief Justice had imported a reasonableness test into minimal impairment analysis. ${ }^{6}$ In effect, deference condones rational rather than minimal impairment, although the Court has not changed its terminology to reflect this transformation.

Law v. Canada (Minister of Employment and Immigration), [1999] 1 S.C.R. 497 [hereinafter Law, SCC].

2 Canada Pension Plan, R.S.C. 1985, c. C-8, ss. 44(1)(d) and 58(1)(a) [hereinafter CPP].

3 Canadian Charter of Rights and Freedoms, Part I of the Constitution Act, 1982, being Schedule B to the Canada Act 1982 (U.K.), 1982, c. 11 [hereinafter Charter], s. 15(1) which provides:

Every individual is equal before and under the law and has the right to the equal protection and equal benefit of the law without discrimination and, in particular, without discrimination based on race, national or ethnic origin, colour, religion, sex, age or mental or physical disability.

R. v. Chaulk, [1990] 3 S.C.R. 1303 at 1388

5 v. Oakes, [1986] 1 S.C.R. 103 created two tests, one of which contained three branches, that had to be met before legislation found in violation of a Charter right could nevertheless be "saved" under section 1.

6 Supra note 4 at 1343, per Lamer C.J.: "In enacting s. 16(4), Parliament may not have chosen the absolutely least intrusive means of meeting its objective, but it has chosen from a range of means which impair \$. 11(d) as little as is reasonably possible." As recently as Corbière v. Canada (Minister of Indian and Northern Affairs), [1999] 2 S.C.R. 203 at para. 21 [hereinafter Corbière], McLachlin and Bastarache JJ. wrote that "it has not been demonstrated that \$. 77(1) of the Indian Act impairs the s. 15 rights minimally;" and L'Heureux-Dubé J., concurring, wrote
Therefore, since it is found in Charter jurisprudence only at the minimal impairment stage of section 1 proportionality analysis, deference could play no role in Law. Absent a violation of Charter rights, the Court found it unnecessary to turn to section 1 analysis.

This outcome was somewhat curious in light of facts contained in a report on the Canada Pension Plan authored by Terry De March. ${ }^{8}$ Not only was his report accepted into evidence by the three judges who composed the Pension Appeals Board, '? but portions of it were repeated in the Board's decision "because they can assist the reader to obtain a broad perspective on and understanding of the Canada Pension Plan's development and objectives." ${ }^{10}$ Although the Federal Court of Appeal made no reference to it, ${ }^{11}$ and the Supreme Court of Canada made only one oblique reference, ${ }^{12}$ there are two reasons why the De March

at para. 103 "[T] hose seeking to uphold this law have not demonstrated that a complete exclusion of non-residents from the right to vote, which violates their equality rights, constitutes a minimal impairment of these rights" (emphasis added).

s Nancy Law v. The Minister of Employment and Immigration (1995), C.E.B. \& P.G.R. 8574 [hereinafter Law, PAB], wherein Rutherford J. described De March at 6076 as "Chief of Legislative Development in the Policy and Legislation Division, Income Security Programs Branch of the Department of Human Resources Development. Mr. De March has some 17 years [sic] experience in a variety of increasingly senior posts in the Government of Canada, all related to various aspects of the administration, implementation and amendment of the Canada Pension Plan. The Board accepts his unique and substantive background and experience as enabling him to assist the Board in understanding the Plan's background and development as well as the policies and objectives it has been designed to address."

$9 \quad \mathrm{lbid}$. at 6074 , Rutherford J. noting the Board "is made up of judges and former judges of the superior and appellate courts of the provinces."

10 Ibid. at 6076

1 Law v. Canada (Minister of Employment and Immigration), [1996] 1 F.C.J. No. 511 [hereinafter Law, FCA].

12 Law, SCC, supra note 1 at para. 15: "Following an extensive extract from the respondent's expert report, adduced at the trial de novo before the Pension Appeals Board, Rutherford J. stated that although many laws create legal distinctions, not all amount to discrimination within the meaning of s. 15(1) of the Charter." In addition, in paras. 8 and 97 , the Court quoted from two quotations contained in the De March report, albeit without 
report was indeed relevant to deciding Law. First, it referred to five recent federal reports that had resulted at least in part from questions about the constitutionality of age limits on Canada Pension Plan survivor benefits, ${ }^{13}$ which was the central issue in Law. Nevertheless, in Law's opinion, these reports merited a single generic reference - one that left the misleading impression that the appellant alone had raised them. ${ }^{14}$ Second, the De March report made it clear that all but the first of these five federal reports had recommended changes to the age limits on Canada Pension Plan survivor benefits, whether for reasons of constitutionality or changing social conditions. ${ }^{15}$ In addition, De March pointed out that after the first of these reports had appeared, the federal government "acknowledged that the current criteria may no longer be appropriate."16 Yet again, Law's opinion was silent, containing no hint either of this acknowledgment or of the recommendations of these five federal reports. ${ }^{17}$

Given the durability and consistency of the pressures for changing Canada Pension Plan survivor benefits, it is surprising that the Minister failed to concede, and the

indicating whether it was their source. Interestingly enough, there was a slight variation between the citation in para. 8 and the corresponding citation in the De March report, leaving it open to speculation whether the former was a correction or typo.

13 Law, PAB, supra note 8 at 6081 , referring to: (i) the Report of the Parliamentary Task Force on Pension Reform (The "Frith" Report) 1983; (ii) Equality for All, Report of the Parliamentary Committee on Equality Rights, 1985; (iii) Toward Equality, The Response to the Report of the Parliamentary Committee on Equality Rights, 1985; (iv) Survivor Benefits under the Canada Pension Plan, a Consultation Paper released in 1987; and (v) the Report on the Consultation Paper by the Standing Committee on National Health and Welfare in 1988.

14 Law, SCC, supra note 1 at para. 100: "Before answering these questions, it is useful to note that, although the appellant has referred this Court to government reports and other sources which favour extending survivor's pensions to younger spouses ..."

15 Law, PAB, supra note 8 at 6081 , quoting from the De March report that: (i) the Frith Report "stated that ... further study of the CPP survivor's benefits was required in order to identify why changes were needed and who would gain or lose from such changes;" (ii) Equality for All "recommended that benefits under the CPP be awarded without reference to age, family status or disability:" (iii) in Toward Equality "the Government recognized that social programs must evolve to reflect changing social conditions and that the Government intended to work with the provinces in an effort to reach a consensus on reform;" (iv) the Consultation Paper was the culmination of "extensive discussions between federal and provincial officials" which had occurred after the federal government "acknowledged that the current criteria may no longer be appropriate and stated its intention to work with the provinces to arrive at a consensus on this issue; and (v) the Report on the Consultation Paper by the Standing Committee on National Health and Welfare "supported the major thrust of the paper but suggested some fundamental changes in benefit structure."

16 lbid.

17 Supra note 1. See comment reproduced at note 14
Court failed to find, that the age limits violated Charter equality rights. After all, that would not have ended the matter. Rather, it would merely have shifted the burden onto the government to show why the infringement should be saved under section 1. Even absent any intrinsic reason, the federal government would have had a strong federalism argument. Pensions were originally a provincial responsibility under the Constitution Act, 1867 and this did not change until 1951 when section 94A was added (and revised in 1964) to enable Parliament to legislate with respect to old age pensions and supplementary benefits, including survivors' and disability benefits. ${ }^{18}$ Since section $94 \mathrm{~A}$ also provides that federal pension laws cannot affect the operation of provincial pension laws, at best the situation is one of concurrent powers. ${ }^{19}$ Concurrency alone would have given the Court pause in its section 1 analysis; and when taken in combination with the existence of on-going federal-provincial negotiations aimed at reaching a consensus, as well as of "analytical work on several options" being "currently underway," as evidenced in De March's report, ${ }^{20}$ it is not difficult to imagine the Court sustaining a section 1 argument even if only temporarily. ${ }^{21}$

Deference and even hyperdeference ${ }^{22}$ aside, why did the Canadian Supreme Court decide to hear Law? After all, it had gone through four levels of appeal involving at least ten appellate decision-makers. ${ }^{23}$ Why add the nine more Court voices to the nine that had already denied

18 British North America Act, 1951 (U.K.), 14-15 Geo. VI, c. 32, as amended by the Constitution Act, 1964 (U.K.), 12-13 Eliz, II, c 73.

19 P.W. Hogg, Constitutional Law of Canada, stud. ed. (Scarborough: Carswell, 1999) at 385.

20. Law, PAB, supra note 8 at 6081 .

21 Ibid. at 6085 wherein Rutherford J. held: "In the context of the Canada Pension Plan with its complexities, cross-subsidizations, inter-relationships with other support-benefit programs and initiatives and its federal-provincial support base and amendment formula, the courts and administrative tribunals which must consider legal challenges of the kind raised in this case should exercise the greatest deference and restraint before invalidating any part of such legislation on Charter grounds."

22 Hyperdeference is a term I derived by combining "hyper," meaning "excessive," with the ordinary, not legal, meaning of "deference," which refers to courts refusing to second-guess legislative policy choices. I use it to describe a decision such as Law wherein the Court upholds the impugned legislation without ever finding a rights violation.

23 Subsequent to the original refusal of benefits, the first appeal was directed to the Minister of National Health and Welfare; the second, to the Pension Plan Review Tribunal (unreported, but referred to in Law, SCC, supra note 1 at para. 12) which consisted of at least three members; the third, to the Pension Appeals Board (supra note 8) which consisted of Dureault, J., Chairman; Rutherford, J., Vice-Chairman; and Angers, J.A., and the fourth, to the Federal Court of Appeal (supra note 11) which consisted of Isaac C.J., Stone and McDonald JJ. 
Nancy Law's claim? ${ }^{24}$ Interestingly enough, the judges also felt some obligation to respond to that question. According to Justice Iacobucci, the Court decided Law "in order to provide a set of guidelines for courts that are called upon to analyse a discrimination claim under the Charter." 25 Seemingly, the case provided "a useful juncture at which to summarize and comment upon [the basic principles relating to the purpose of s. 15(1) and the proper approach to equality analysis]." ${ }^{26}$ However, it is unclear why it was timely. Although Justice Iacobucci preferred to "believe it is fair to say that there has been and continues to be general consensus regarding [these basic principles]," he also acknowledged that "there have been differences of opinion among the members of this Court as to the appropriate interpretation of s. 15(1)."27 Astoundingly, he then wrote a further 108 paragraphs without setting out any of these differences. This smacks of damage control.

There are other indications that Law's ambition might be vintage damage control. Not least was its eschewal of the recent and robust factionalism that permeated virtually every paragraph of the equality trilogy ${ }^{28}$ in favour of a bland, pedantic portrayal of judicial unanimity. The decision was itself authored, perhaps strategically, by the Justice whom Canada's national newspaper has characterized as "neutral, or at least unpredictable." 29 Further, it lacked at least two of the features that have frequently served as indicia of serious late-twentieth-century constitutional jurisprudence - namely, there were no equality writings included among the three items set out on the unusually short list of "Authors Cited"30 and, more significantly, no interveners. Of course, Law involved the deferral of survivor benefits to retirement age (assuming the equality seeker lived that long) rather than their outright denial, and it was grounded in age and not sex discrimination, which combined to make it an unlikely candidate for social activism. Finally, and most significantly, Law's

34 The lone dissenter was a member of the Pension Plan Review Tribunal who, according to Lacobucci J. ( $L a w$, SCC, supra note 1 at para. 12), "found that the age distinctions in the impugned provisions were arbitrary and that Parliament could have targeted needy dependents without discrimination by legislating a test to determine need."

25 lbid., para. 5.

20 lbid.

27 lbid., writing for a unanimous Court.

23 Miron v. Trudel, [1995] 2 S.C.R. 418 [hereinafter Miron]; Egan v. Canada, [1995] 2 S.C.R. 513 [hereinafter Egan]; and Thibaudeau v. Canada, [1995] 2 S.C.R. 627.

29 S. Fine, "Lose Mr. Justice Iacobucci and you lose all: Sexual Assault/A review of 24 cases before the Supreme Court of Canada shows how one man tips the scales of justice" The Globe and Mail (11 November 1994) A1 at A6.

3) Law, SCC, supra note 1 at 506 citing two different excerpts from the Debates of the House of Commons in 1964, as well as Sopinka et. al.'s treatise on Evidence. opinion contained not a whiff of the section 15(1) relevancy test propounded by Justice Gonthier in Miron $^{31}$ and relied upon by Justice La Forest in Egan, ${ }^{32}$ Yet this test was so controversial as to be conspicuous by its omission. Does Law's reticence mean it has been laid to rest? Or does it soldier on in another guise? Might some reference to it have put the Court's consensus in jeopardy?

The articulation of the relevancy test threatened, and was intended to threaten, equality seekers. Thus it is important to understand whether it is really gone or whether the Court has reconstituted it. Before considering this issue, however, I want to briefly set out Law's context and outline Justice Iacobucci's opinion. Thereafter, I intend to argue that aside from formatting section 15(1) equality analysis, Law's approach drastically curtails it. Clearly, this happened to Nancy Law's claim. Moreover, not only does this approach evidence a re-articulation of the relevancy test in the guise of what are called "contextual factors," it is at odds with the purpose of section $15(1)$ as Justice Iacobucci crafted it. In sum, I conclude that consistency requires the Court either to redefine the meaning of equality rights or to change its approach to equality analysis. Otherwise, it will be perceived not as adjudicating but as controlling Charter equality rights.

\section{CONTEXT}

The facts are simple. In 1991, at the age of thirty, Nancy Law was widowed when Jason Law, her husband of ten years, died at the age of fifty. Since he had contributed to the Canada Pension Plan for twenty-two years, she applied for survivor's benefits. Her application was refused because the Plan is structured to defer benefits until retirement age if surviving spouses have neither dependent children nor disability and are under the age of thirty-five. Irrespective of dependent children or disability, surviving spouses over the age of forty-five receive full benefits while those between the ages of thirty-five and forty-five receive gradually reduced benefits. ${ }^{33}$ Not surprisingly, Nancy Law believed the Plan discriminated on the grounds of age.

The De March report traced the legislative evolution of survivor's benefits under the Canada Pension Plan. ${ }^{34}$ There were four reasons for their inclusion: the fact that

\footnotetext{
Miron, supra note 29.

Egan, supra note 29.

3) According to Law, PAB, supra note 8 at 6077 , in 1995 , the maximum amount payable to a survivor under age sixty-five was $\$ 392.24$; for a survivor over age sixty-five, the maximum was $\$ 427.91$.

34 lbid.
} 
Québec proposed to include them in its plan provided the initial impetus; the expectation that most husbands were the primary financial providers meant that the husband's death created a need on the part of the surviving wife; the belief that pension contributions were deferred wages which should return to the family in an annuity form; and the desire to entitle survivors to some financial assistance as a matter of right rather than imposing on them the stigma of having to rely on social assistance. Given these rationales, it is not surprising that the initial act that was passed in 1965 provided differentially for male and female survivors, although this was changed in 1975. In 1986, a legal definition of spouse was added; it included common-law, but not gay and lesbian, relationships. As well, the provision terminating survivor's benefits on remarriage was repealed. A provision entitling the surviving spouse to the greater of the survivor's benefits in the case of more than one death was also added.

In fact, the De March report also provided estimates of the costs of eliminating the under-forty-five age criteria. ${ }^{35}$ Including reinstatement of those previously ineligible due to the age rules, the costs would approximate $\$ 60$ million in the first year of implementation. These represent permanent additional costs to the Plan. By the year 2020 the costs would have risen to $\$ 213$ million. Ultimately, contribution rates would have to be raised beyond the gradual increases in place since 1987. However, the report did not include any specific information on how steeply contribution rates would have to increase if the age limits were removed.

\section{OPINION}

Justice Iacobucci's opinion had three dimensions. First, he surveyed the Court's prior jurisprudence pertaining to the meaning of section 15 (1) equality rights, thereby positioning himself to forge a consensus on the purpose of that section. Next, he reviewed the ways in which the Court had previously approached Charter equality rights, saving only the relevancy test, and proceeded to format them "as guidelines for analysis." 36 Finally, he applied his newly formatted approach to equality analysis to Law's facts, concluding that they did not support a finding of discrimination. I propose to briefly elaborate each of these dimensions in turn.

\section{(i) Purpose of section 15(1)}

After noting that section 15(1) is "perhaps the Charter's most conceptually difficult provision" because equality is "an elusive concept" that has an "exalted

\footnotetext{
35 Ibid.

36 Law, SCC, supra note 1 at paras. 6 and 88.
}

status, " ${ }^{37}$ Justice Iacobucci nonetheless maintained that there was "great continuity in the jurisprudence of this Court on [the purpose of the $s$. 15(1) equality guarantee]." 38 Beginning with Justice McIntyre's statement in Andrews about the purpose of section 15(1) reflecting the recognition of human beings as "equally deserving of concern, respect and consideration," ${ }^{39}$ he moved through similar descriptions in various intervening opinions, including those of Madame Justice Bertha Wilson in McKinney, referring to the "promotion of human dignity;" ${ }^{40}$ Madame Justice Beverley McLachlin in Miron, referring to "human dignity and freedom;" 11 and Madame Justice Claire L'Heureux-Dubé in Egan, referring to "value as human beings or as members of Canadian society." ${ }^{, 42}$ Finally, he cited his own joint opinion with Justice Cory in Vriend, in which they referred to the purpose of section 15(1) in terms of taking "a further step in the recognition of the fundamental importance and the innate dignity of the individual." ${ }^{43}$ Not surprisingly, Justice Iacobucci concluded that "these statements share several key elements," amongst which "human dignity" played a preeminent role. ${ }^{44}$ Under these circumstances, and as an aside, it is hard to figure out why Peter W. Hogg contended Justice Iacobucci's reference to "human dignity" was a "new element" that was "added" to section 15(1) analysis, let alone how Professor Hogg could also justify characterizing it as "the new human dignity approach." ${ }^{.45}$

While Justice Iacobucci referred to the purpose of section 15(1) in terms of "human dignity," it is worth noting that he also described it as having more than one feature. It is practically self-evident that section $15(1)$ is supposed "to prevent ... the imposition of disadvantage, stereotyping or political or social prejudice" because of its reiterated reference to "without discrimination." 46 However, it is even more encouraging to discover Justice Iacobucci also subscribed to the view that section 15 (1)

\footnotetext{
lbid., para. 2.

Ibid., para. 42.

Ibid.

McKinney v. University of Guelph, [1990] 3 S.C.R. 229 at 391.

Miron, supra note 29 at para. 131.

Egan, supra note 29 at para. 39.

Vriend v. Alberta, [1998] 1 S.C.R. 493 at para. 67.

Supra note 1 at para. 51.

45 Peter W. Hogg, Constitutional Law of Canada (Scarborough: Carswell, 1997) 5. 52.7 at 52-53 (1999-Rel. 1). At 52-24 Professor Hogg mentioned the "element of human dignity that has now been injected into the s. 15 jurisprudence"; at 52-25 he referred to "the new human-dignity rule"; and at 52-26 he stated that all nine judges in Law had "imported into s. 15 the requirement ... of 'human dignity"," a statement that he repeated at 52-27. Finally, at s. 52.13 at 52-55 Professor Hogg reported again that the decision in Law involved "human dignity (an element of s. 15 that the Court in this case introduced into the jurisprudence for the first time)."

4s Law, SCC, supra note 1 at para 51.
} 
is intended "to promote a society in which all persons enjoy equal recognition at law as human beings or a members of Canadian society, equally capable and equally deserving of concern, respect and consideration. ${ }^{147}$ In other words, section $15(1)$ has two goals: preventing discrimination (or the "evil of oppression," as Justice McIntyre referred to it) ${ }^{48}$ and promoting equality (or "human dignity," as Justice Wilson referred to it) ${ }^{49}$ Regrettably, Justice Iacobucci did not address the consequences of ascribing more than one objective to section 15 (1). Instead, he preferred to rely on the fact that past cases had focused on only one of these objectives, namely "the goal of assuring human dignity by the remedying of discriminatory treatment." ${ }^{, 50}$ Therefore, until the Court confronts a case requiring it to intervene in order to promote human dignity, we can only speculate about the relevance of that feature of section $15(1)$ analysis.

Justice Iacobucci was more forthcoming about the meaning of human dignity. After noting that in Rodriguez, Chief Justice Lamer portrayed section 15(1) as being "concerned with the realization of personal autonomy and self-determination," Jit Justice Iacobucci proceeded to offer his own rendition of how the Court's previous jurisprudence delineated the meaning of human dignity. "Human dignity means," he wrote, "that an individual or group feels self-respect and self-worth." Continuing, he maintained that human dignity "is concerned with physical and psychological integrity and empowerment." ${ }^{, 53}$ Accordingly, while human dignity is harmed by unfair treatment and marginalization, it is enhanced by sensitivity and recognition. ${ }^{54}$ Ultimately, Justice Iacobucci concluded that human dignity "does not relate to the status or position of an individual in society per se, but rather concerns the manner in which a person legitimately feels when confronted with a particular law," 55 Given the lengths to which he went to elaborate

Ibid.

Andrews v. Law Society of B.C., [1989] I S.C.R. 143 at 180-81.

McKinney, supra note 41 .

Ibid., para. 52.

5 Rodriguez v. British Columbia (A.G.), [1993] 3 S.C.R. 519 at 554.

52 Law, SCC, supra note 1 at para. 53.

$\$ 3$ Ibid.

S4 Ibid., stating: "Human dignity is harmed by unfair treatment premised upon personal traits or circumstances which do not relate to individual needs, capacities, or merits. It is enhanced by laws which are sensitive to the needs, capacities, and merits of different individuals, taking into account the context underlying their differences. Human dignity is harmed when individuals and groups are marginalized, ignored, or devalued, and is enhanced when laws recognize the full place of all individuals and groups within Canadian society."

s5 Ibid., continuing: "Does the law treat him or her unfairly, taking into account all of the circumstances regarding the individuals affected and excluded by the law?" his meaning, it is hard to see how Professor Hogg could maintain that the Court's reliance on the element of human dignity is "vague" and "confusing.,"56

Moreover, Justice Iacobucci's elaboration makes it easy to understand his insistence that the "overriding concern" of section 15(1) is "protecting and promoting human dignity. ${ }^{157} \mathrm{He}$ failed, however, to explain why he asserted that determining "whether the fundamental purpose of s. 15(1) is brought into play in a particular claim" makes it "essential to engage in a comparative analysis., ${ }^{58}$ When Justice McIntyre rejected the American "similarly situated" test in Andrews, ${ }^{59}$ some of us dared to hope this rejection would be extended to comparative analysis in general. ${ }^{60}$ The spuriousness of the similarly situated test derived from the false comparisons that had been forged in many of the Canadian Bill of Rights cases. ${ }^{61}$ Comparative analysis is no less vulnerable to such comparisons absent the rhetoric of the similarly situated test. Another way to express this concern is to point out that comparison and the promotion of human dignity are inherently antithetical processes. In effect, comparison abstracts and generalizes, whereas human dignity - or in Justice Iacobucci's words, how an individual "feels" - could not be more specific and particularized. That Justice Iacobucci has not as yet recognized the incongruity of his approach is, of course, not to despair of future enlightenment.

56 Hogg, supra note 46, s.52.7 at 52-24, On the one hand, Professor Hogg seems to have an aversion for human dignity, claiming "the concept of human dignity is inherently vague and unpredictable in its application." On the other hand, Justice lacobucci never pretended to define human dignity in the abstract. Rather, he readily acknowledged there could "be different conceptions of what human dignity means:" and he claimed he was relying on the Court's jurisprudence, which he stated, "reflects a specific albeit non-exhaustive, definition:" Law, SCC, supra note I at para. 53. Could this be merely a conflict of semantic dimensions between antediluvian titans?

5 Law, SCC, supra note 1 at para. 54

53 lbid., para. 55 .

99 Andrews, supra note 49 at 166: "The similarly situated test is a restatement of the Aristotelian principle of formal equality.... The test as stated, however, is seriously deficient in that it excludes any consideration of the nature of the law. If it were to be applied literally, it could be used to justify the Nuremberg laws of Adolf Hitler. Similar treatment was contemplated for all Jews."

60 Ibid. at 164, where Justice McIntyre explicitly failed to take this step, saying instead that equality "is a comparative concept, the condition of which may only be attained or discerned by comparison with the condition of others in the social and political setting in which the question arises." In Law, SCC, supra note 1 at para. 24 , Justice lacobucci repeated this statement.

61 Ibid. at 166-8, referring to its application in Gonzales (BCCA) and Bliss (SCC) and its rejection in Drybones (SCC). 


\section{(ii) Contextual factors}

In summarizing the approaches to section 15(1) analysis that the Court had relied upon in previous equality cases, Justice Iacobucci turned once again to Andrews for his starting point. He set out the three key elements Justice McIntyre had identified: "differential treatment, an enumerated or analogous ground, and discrimination in a substantive sense involving factors such as prejudice, stereotyping and disadvantage." ${ }^{\text {. }}$ Justice Iacobucci traced these elements through intervening cases, particularly Miron and Egan, both of which he characterized as setting out a two-step approach. ${ }^{63}$ Thus, he conveniently overlooked the third or relevancy step promoted by Justices Gonthier and La Forest. Again, he claimed to synthesize the previous articulations, this time into "three broad inquiries" that nevertheless very closely resembled Justice McIntyre's original three elements. ${ }^{64}$ However, in the process of elaborating on the third or discrimination inquiry, Justice Iacobucci extended it beyond Justice McIntyre's original conception. While Justice McIntyre was content to define discrimination in terms of historical disadvantage, prejudice and stereotyping, Justice Iacobucci opted to import three additional factors that he categorized as "contextual." In other words, only the first of his four contextual factors - "pre-existing disadvantage" correlated with his predecessor's approach.

The three remaining contextual factors identified by Justice Iacobucci were: the extent to which the legislation takes into account the need, capacity or circumstances of the claimant; whether the purpose or effect of the law is the amelioration of the greater need or the different circumstances of a disadvantaged person or group; and the "nature and scope of the interest affected by the ... law," viz. whether it has "severe and localized consequences for the affected group. ${ }^{166}$ To the extent that these three factors are novel, it is only by comparison with Justice McIntyre's opinion in Andrews. The reality is that each derives from one or more of the section 15(1) decisions that the Court has rendered since Andrews. In effect, these factors are internally distinguishable only in so far as Justice Iacobucci could attribute each one mainly but not entirely to a different jurisprudential source. In other words, he drew his emphasis on the claimant's actual situation mainly from Justice Sopinka's opinion in Eaton; his focus on amelioration, mainly from Justice La Forest's decision in Eldridge; and his concern for consequences, mainly from the Justice L'Heureux-

\footnotetext{
62 Law, SCC, supra note 1 at para. 30

6) Ibid., paras. 32, 33 and 39

64 lbid., para. 39

65 lbid., para. 62.

lbid., para. 88 at 552
}

Dube's dissent in Egan. ${ }^{67}$ Thus, even in developing this portion of his opinion, which most accurately could be called his unique contribution, Justice Iacobucci was quintessentially formatting rather than advancing the Court's approach to section 15(1) equality analysis. Of course, it is as important to assume responsibility for the consequences of formatting as it is for those of any other intervention.

\section{(iii) Application}

When it came to applying the third or discrimination inquiry - that is, the four contextual factors - to Law's facts, Justice Iacobucci began simply by asserting that: "Relatively speaking, adults under the age of forty-five have not been consistently and routinely subjected to the sorts of discrimination faced by some of Canada's discrete and insular minorities. ${ }^{168} \mathrm{He}$ might be right or he might be espousing a stereotype, but how to tell? Without more, who's to say whether adults over forty-five or their counterparts under forty-five are the more disadvantaged? More concretely, if this issue, which is crucial to Law's claim, must be evaluated from the perspective of "a reasonable person in circumstances similar to those of the claimant," ${ }^{, \infty}$ what qualifies the members of the Court, all of whom currently are over fifty? The easy answer is that all have lived through the under-forty-five years. ${ }^{70}$ The harder problem is that not only times but also perspectives may change as we age. Consider for example the perspective of today's younger generations, especially those who faced incredibly high rates of unemployment when they tried to enter Canada's labour force during the past decade. I suspect at least some of them would have experienced debilitating circumstances that might prompt them to strongly disagree with Professor Hogg's assertion that "[a] minority defined by age is much less likely to suffer from the hostility, intolerance and prejudice of the majority than is a minority defined by race or religion or any other characteristic that the majority has never possessed and never will possess." ${ }^{31}$ These selfsame unemployed youth also might question whether someone over fifty who claimed that people under thirty-five can more easily find or maintain employment than those who are over thirty-five really understood the "reality" contemporary Canadian workforce from their perspective.

\footnotetext{
Ibid., paras. 62-74.

Ibid., para. 95.

Ibid., para. 60

To Hogg, supra note 20 at 1027 , observing "Each individual of any age has personally experienced all earlier ages ...."

21 Ibid.

7 Hogg, supra note 46 at 52-55.
} 
Moreover, Justice Iacobucci exacerbated his failure to analyse whether there was a pre-existing disadvantage posed by age by assuming Canada Pension Plan survivor benefits "concern, not the relatively immediate financial needs of surviving spouses, but their long-term financial needs." ${ }^{73}$ While he accurately attributed this assumption to statements made by the Minister when the Plan was first introduced in the House, he neglected to mention the intervening amendments detailed in the De March report that have all but obviated the original rationales for limiting these benefits on the grounds of sex and age. ${ }^{74}$ Finally, Justice Iacobucci appeared to entirely abandon his "contextual factors" when he conceded, "Yes, the law imposes a disadvantage on younger spouses in this class," and then immediately added, "But it is unlikely to be a substantive disadvantage, viewed in the long term. ${ }^{\text {"75 }}$ Insofar as this unsubstantiated speculation was addressed to Nancy Law, who had unsuccessfully endeavoured to continue after her husband's death in the small business they had co-owned, ${ }^{76}$ it is difficult to appreciate just how it exemplified the "subjective-objective" focus on discrimination advocated by Justice L'Heureux-Dubé in Egan and adopted by Justice Iacobucci in Law. ${ }^{77}$

\section{Critique}

In what follows, I critically assess only the consequences of Law's failure to advert explicitly to the third test expounded in the trilogy. In Miron and Egan, Justices Gonthier and La Forest intruded a relevancy test into section 15(1) equality analysis. While in neither case did a majority of their colleagues join in their advocacy of this test, all but a majority shared their view in both cases. According to this test, if the impugned legislative distinction was based on a personal characteristic that the Court believed was relevant to the fundamental values underlying the legislation, there was no violation of the section 15 (1) equality rights. If adopted, this test would have two consequences. First, as with the reasonableness or minimal scrutiny test in American equal protection jurisprudence, this test would make it rare for a court to refuse to uphold legislation under section 15(1) analysis. Fundamentally, it assumes legislative ignorance (of equality rights) in enacting legislation - a belief that is unreal, at least in the era of the Charter in Canada. What it neglects, in turn, is the majority's deliberate and wellrationalized incursion into minority rights. Second, it also follows that section 1 will be underutilized, governments

\footnotetext{
Law, SCC, supra note 1 at para. 98.

Ibid., para. 97, 102, 103, 104 and 106.

Ibid., para. 102.

T6 Ibid., para. 10, noting she "was responsible for business operations and her husband had the requisite technical knowledge and expertise."

77 Ibid., paras. 59 and 61 .
}

will have fewer burdens of justification to meet and the occasions for their owning as well as explaining an interference in minority rights will all but disappear. Thus, the relevancy test threatened, and was intended to threaten, equality seekers.

Under these circumstances, I deeply regret having to suggest that Law's opinion did not lay this test to rest. ${ }^{78}$ I would be delighted to be proved wrong. In the meantime, I contend the relevancy test underlies, both directly and indirectly, the three contextual factors Justice Iacobucci identified anew. Consider the first of these factors. It requires the Court to assess the extent to which the impugned legislation takes the claimant's actual situation into account, with the result that "legislation which takes into account the actual needs, capacity or circumstances of the claimant ... will be less likely to have a negative effect on human dignity." for "actual needs" seems not unlike espousing fundamental values. In both cases they are relied upon to excuse what would otherwise constitute discrimination. In Nancy Law's case this meant accepting the age limits on Canada Pension Plan survivor benefits on the ground that they valued the employability (or actual need), if not the marriageability, of younger surviving spouses. ${ }^{80}$ Similarly the second contextual factor which holds that laws with "ameliorative purposes or effects" are not likely to "violate the human dignity of more advantaged individuals," sustaining values that are fundamental. Again, in Nancy Law's case this meant recognizing that Canada Pension Plan survivor benefits distinctions had an ameliorative purpose insofar as they actually provided remediation for older, albeit not younger, surviving spouses. ${ }^{82}$ Finally, since the third or "nature of the interest affected" factor holds that the legislative intervention must be not only severe and localized but also economically as well as constitutionally and socially significant to qualify as

79 Ibid., para. 70.

80 lbid., para. 101 stating: "It seems to me that the increasing difficulty with which one can find and maintain employment as one grows older is a matter of which a court may appropriately take judicial notice." Or para. 104: "A reasonable person under the age of forty-five who takes into account the contextual factors relevant to the claim would properly interpret the distinction created by the CPP as suggesting that younger people are more likely to find a new spouse, are more able to retrain or obtain new employment, and have more time to adapt to their changed financial situation before retirement."

sI Ibid., para. 72.

\$2 Ibid., para. 102, stating: "By being young, the appellant, a fortiori, has greater prospect of long-term income replacement." Again, at para. 104: "Young people are inherently better able to initiate and maintain long-term labour force participation, and as such the impugned CPP provisions cannot be said to impose a discriminatory disadvantage upon them." 
discriminatory, ${ }^{83}$ it also resonates with upholding laws that are consistent with fundamental values. Indeed, Nancy Law's downfall was that the interests affected by Canada Pension Plan survivor benefits were ostensibly expressed in terms of long-term, rather than short-term, security for surviving spouses. ${ }^{84}$

In sum, irrespective of whether a legislative distinction is based on historical disadvantage, prejudice or stereotype, the Court can find that it is not discriminatory if it is also based on the claimant's needs, ameliorative benefits or affected interests. Applied to $L a w$, it was evident from its inception that the Canada Pension Plan had denied benefits to women under thirtyfive who were surviving spouses (i.e., historical disadvantage). This denial was triggered by their youthful age (i.e., prejudice). And it presumed they wanted remarriage and were employable (i.e., stereotype). ${ }^{85}$

However, Justice Iacobucci held that the age distinction was not discriminatory or, more accurately, he stated: "Yes, the law imposes a disadvantage on younger spouses in this class. But it is unlikely to be a substantive disadvantage, viewed in the long term. ${ }^{186}$ To the contrary, it became an acceptable distinction "when the dual perspectives of long-term security [i.e., affected interests] and the greater opportunities of youth [i.e., claimant's needs] are considered." 87 More specifically, he held Nancy Law "is more advantaged by virtue of her young age [i.e., ameliorative benefits]." 8 Under these circumstances, whether the three contextual factors proposed by Justice Iacobucci were considered individually or in combination, they made the Canada Pension Plan survivor benefits age distinction not only relevant (or acceptable) but also legal (or permissible). Perhaps Law's lesson is to teach us to be cautious when all the ducks line up so easily in a row, notwithstanding whether it is in the Court's interest to propagate it.

83 lbid., para. 74

\$4 Ibid., para. 100, stating that "the purpose and function of the impugned CPP provisions is not to remedy immediate financial need experienced by widows and widowers, but rather to enable older widows and widowers to meet their basic needs during the longer term." Or para. 104, "[П] it is open to the legislature to use age as a proxy for long-term need."

8s Ibid., para. 96, where Justice lacobucci set this out as one of the appellant's arguments. Cf. para. 108, where he subsequently denied its merit: "The impugned distinctions in the present case do not stigmatize young persons, nor can they be said to perpetuate the view that surviving spouses under age forty-five are less deserving of concern, respect or consideration than any others. Nor do they withhold a government benefit on the basis of stereotypical assumptions about the demographic group of which the appellant happens to be a member."

lbid., para. 102

87 lbid.

84 lbid., para. 105
Even were I not persuasive about imputing the relevancy test directly to these three contextual factors, I would nonetheless contend that they are indirectly related to it. In effect, these factors share three similar consequences with this test. First, they evince the same underlying negativity with respect to promoting equality rights as did the relevancy test. Semantics notwithstanding, these three contextual factors are designed as impediments that equality seekers much overcome rather than as assistive devices. ${ }^{89}$ For some peculiar reason, the Court seems afraid to develop a section 15 (1) equality rights test that is as permeable as the Irwin Toy test with respect to infringements of the right to freedom of expression. ${ }^{90}$ Second, since the three contextual factors resemble the relevancy test in that they burden the equality seeker's case, the result is that neither approach burdens the government. Indeed, the government is never required to justify the legislative distinction under section 1 because the equality seeker cannot meet the onerous (and seemingly, ever increasing) requirements of section $15(1)$. I agree with Professor Hogg's contention that Law's approach blurs the relationship between section 15 (1) and section 1 such that most, if not all, of the analysis takes place in section $15(1){ }^{91}$ Where we differ is in our identification of the cause. He attributed the collapse to the "new element of human dignity," whereas I fault the three ostensibly new contextual factors. Third, the three factors newly identified as contextual by Justice Iacobucci are no more self-evident, nor fundamental, than the values recognized as relevant by Justices Gonthier and La Forest in Miron and Egan respectively.

In effect, Law's three factors are demonstrably overinclusive when we examine who benefits, or might benefit, from Canada Pension Plan survivor benefits simply because they are over forty-five. Consider that such benefits would be routinely awarded not only to female, but also male, vice-regal spouses irrespective of whether their mates were federal or provincial appointees; not only to female, but also to male, administrators and/or academics whose salaries of over $\$ 100,000$ are a matter of public record, yet who may have spouses who work and therefore contribute to the Canada Pension Plan; or even to judges, who have spouses who

m) Professor Hogg, supra note 46, s. 52.7 at 52-25 also voiced this critique, although he attributed it to the new element of human dignity; in contrast, I limit it specifically to these three contextual factors.

50 Irwin Toy Limited v. Québec (Attorney General), [1989] I S.C.R. 927.

91 Professor Hogg, supra note 46, s. 52.7 at 52-25 portrayed Law's decision as confusing the relationship between section 15 and section 1 and leaving section 1 "with little work to do;" and at $52-26$ as suffering from the vice of blurring "the roles of s. 15 and $s .1 . "$ 
also work and contribute to the Canada Pension Plan, including current members of the Court. These readily imaginable possibilities make it hard to look Nancy Law in the eye and maintain that her "human dignity" has not been impaired by the age limits of the Canada Pension Plan survivor benefits regime.

\section{Conclusion}

Fortunately, the Court did not maintain that Law's opinion was the last word on section $15(1)$ equality analysis. Hopefully, the Court will opt to bring its contextual analysis more into line with its delineation of that section's purpose. Clearly, I share the Court's designation of human dignity as a primary, if not the primary, purpose of section 15(1). The genealogy of human dignity as a philosophical inspiration and as an aspiration with internationally defined dimensions is well recognized. In my view, Professor Hogg was right to criticize Law's opinion for coming "close to saying that the legislative distinction must be invidious"and for being "inconsistent with the ruling in Andrews." ${ }^{, 92}$ However, I suggest that he threw out the baby with the bathwater when he condemned the goal of human dignity, rather than simply eschewing the three additional contextual factors that Justice Iacobucci had formatted. While the Justice's formatting treats equality seekers egregiously, his reliance on human dignity will still save some babies, as the Court's subsequent decisions in $M$. v. $H$. and Corbière v. Canada illustrate. ${ }^{93}$

I am more pessimistic about the Court's ability to re-vision its perspectives on age-based legislative distinctions. The Court's record on age is almost as bad as its record on sex, ${ }^{94}$ even though the judges did recognize that section $15(1)$ had been violated in McKinney. ${ }^{95}$ That case revealed the Court's vulnerability to age-based equality claims, not least because it upheld legislation permitting mandatory retirement policies to prevail in Ontario for persons over sixty-five even though federally appointed judges can themselves sit till they reach the age of seventy-five. As well, the split opinions in McKinney revealed that the bench was unable to agree about who was disadvantaged; namely, whether it was those who were forced to retire at sixty-five or the under- sixty-fives waiting for the vacated jobs. Since the contextual factors formatted in Law require the Court to take a position on who is advantaged and who is disadvantaged, Law's consensus may yet come unglued. Were some members of the Court finally to acknowledge their partiality towards age classifications, perhaps they would consider re-visiting Nancy Law's claim or advocate adding age to the factors pertinent to ensuring that future judicial appointments are sufficiently diverse to meet twenty-first-century constitutional needs.

\section{Beverley Baines}

Faculty of Law, Queen's University.

92 Ibid., s. 52.7 at 52-27, although his self-indulgence surfaced when he continued: "If this new doctrine becomes firmly established, this section of this chapter will have to be eliminated as heresy, despite the soundness of the original Andrews rule," M. v. H., [1999] 2 S.C.R. 3; and Corbière, supra note 7 .

Beverley Baines, "Another Century of Inequality" (paper delivered at the Massey College/School of Graduate Studies Symposium, Stepping forward, Stepping back: Women's Equality at Century's End, University of Toronto, 3 March 2000),

s5 McKinney, supra note 41. 